\title{
A CLINICAL COMPARISON OF PROPANIDID AND THIOPENTONE AS INDUCTION AGENTS TO GENERAL ANAESTHESIA*
}

\author{
J. E. WYNANDS, M.D., C.M., AND G. S. Fox, M.D., F.R.C.P. (c) $\dagger$
}

PropanibD, an ultra short-acting non-barbiturate compound, has been successfully used as an intravenous anaesthetic agent..$^{1-5}$ Dundee and Clarke have compared thiopentone, propanidid, G29505, and methohexitone as intravenous agents. ${ }^{4}$ The purpose of this investigation was to compare thiopentone and propanidid as induction agents for short operative procedures.

\section{Method}

Two hundred patients undergoing cystoscopy, with or without retrograde pyelogram, were studied. Half of the patients received 2.5 per cent thiopentone as an induction agent, the remainder received 5 per cent propanidid. On arrival in the operating room, the patients were given atropine $0.4 \mathrm{mg}$. intravenously. No other premedicant drugs were administered, nor were the patients receiving medications for other reasons. When an increase in pulse rate occurred, the patients were induced with either propanidid or thiopentone. If a rise in pulse rate was not obtained, the patients were induced two minutes after the intravenous injection of the atropine. Maintenance of anaesthesia was with $\mathrm{N}_{2} \mathrm{O}\left(6 \mathrm{~L} . / \mathrm{min}\right.$.) and $\mathrm{O}_{2}(3 \mathrm{~L} . / \mathrm{min}$.) by a Magill circuit. Halothane was added in sufficient concentrations to achieve satisfactory general anaesthesia, and thereafter patients were maintained in as light a plane as possible. An attempt was made to anticipate the end of surgery and decrease the concentrations of inhalational agents in order that the patients would be as near awake as possible at the end of surgery.

Using a sphygmomanometer cuff and auscultation, alterations in blood pressure and pulse rate were recorded following the intravenous administration of the induction agent. Eyelid, corneal, pupillary, laryngeal, and pharyngeal reflexes were also assessed. Changes in respiratory patterns were observed.

Emergence from anaesthesia was compared in the two groups. Return to a level of anaesthesia which permitted a response to pain was tested by pinching the patient's shoulder. A satisfactory return to consciousness was considered to be achieved when the patient replied to a simple question, e.g." "What is your address?"

All patients were visited on the wards on the first and second postoperative days. Out patients were contacted at similar intervals at home or office for followup questioning.

-Presented at the Annual Meeting, Canadian Anaesthetists' Society, Banff, Alberta, June 1966.

†Department of Anaesthesia, Royal Victoria Hospital, Montreal, Quebec.

505

Can. Anaes. Soc. J., vol. 13, no. 5, Sept. 1966 
The data collected during the study were tabulated and analysed by an I.B.M. computer no. 7044 .

The distribution of inpatients and outpatients, sex and age, is shown in Table I.

TABLE I

Detalls of Patients Studied

\begin{tabular}{lccccccc}
\hline & Inpatient & Outpatient & Female & Male & Oldest & Youngest & Mean \\
\hline Thiopentone & 74 & 26 & 39 & 61 & 82 & 12 & 52.100 \\
Propanidid & 59 & 41 & 40 & 60 & 80 & 12 & 50.170 \\
\hline
\end{tabular}

Results

The amount of induction agent administered is shown in Table II. From the table it can be seen that the mean dose-weight ratios are comparable. The time interval between the injection and the onset of sleep was also comparable, the longest time being 150 seconds and the shortest 25 seconds in each group. The mean time for thiopentone was 39 seconds as compared to 33 seconds for propanidid.

TABLE II

DOSAGE ADMINISTERED

\begin{tabular}{lccccccc}
\hline \hline & \multicolumn{3}{c}{ Total dose $(\mathrm{mg})$} & & \multicolumn{3}{c}{ mg./kg. dose } \\
\cline { 2 - 4 } & largest & smallest & mean & & largest & smallest & Mean \\
\hline Thiopentone & 475.000 & 175.000 & 271.000 & & 8.636 & 1.923 & 4.126 \\
Propanidid & 475.000 & 175.000 & 332.250 & & 6.798 & $\mathbf{2 . 9 6 6}$ & 4.946 \\
\hline
\end{tabular}

The mean concentration of halothane delivered by a Fluotec vaporizer during the first three minutes of anaesthesia was 2.05 per cent and 3.7 per cent for thiopentone and propanidid respectively. The mean concentration of halothane required for maintenance of anaesthesia was 0.75 per cent with thiopentone, compared to 0.65 per cent with propanidid.

Table III shows the clinical impression of the effectiveness of the amount of induction agent used. Twenty-three per cent of the inductions with propanidid were considered unsatisfactory; this was due to too small a dose being used.

TABLE III

INDUCTION DOSAGE

\begin{tabular}{lcccc}
\hline & Smooth & $\begin{array}{c}\text { Insufficient } \\
\text { dose }\end{array}$ & $\begin{array}{c}\text { Further dose } \\
\text { required }\end{array}$ & Overdose \\
\hline Thiopentone & 80 & 12 & 8 & 0 \\
Propanidid & 76 & 23 & 0 & 1 \\
\hline
\end{tabular}

Figure 1 shows changes in mean blood pressure one minute after the administration of the induction agent. The mean blood pressure was derived from the formula $\left(2 P_{s}+3 P_{d}\right) / 5$, where $P_{B}$ and $P_{d}$ are systolic and diastolic pressures respectively. It is evident that patients induced with propanidid experienced a 
greater fall in mean blood pressure than those induced with thiopentone. In 25 per cent of the thiopentone group mean arterial blood pressure rose or remained stationery, as compared to 6 per cent of the propanidid group. In 33 per cent of the patients receiving thiopentone an 11-30 per cent fall in mean arterial blood pressure occurred, as compared to 55 per cent of those given propanidid. In two per cent of the patients in the thiopentone group a fall greater than 30 per cent of the mean arterial pressure occurred, as compared to 27 per cent of those in the propanidid group. Two of the patients induced with propanidid experienced a fall in mean arterial pressure greater than 50 per cent.

Figure 2 shows the mean blood pressure results at three minutes. At this point the two groups are similar. In 17 per cent of the thiopentone group mean blood pressure rose or remained stationery as compared to six per cent of those receiving propanidid. Sixty per cent of the patients receiving thiopentone experienced a fall in mean pressure of $11-30$ per cent as compared to 71 per cent of those receiving propanidid. In none of the patients did the mean arterial pressure fall by more than 40 per cent.

Figure 3 shows alterations in pulse rate one minute after administration of the induction agent. In 26 per cent of the thiopentone group there was no change or a fall in pulse rate, as compared to 15 per cent in the propanidid group. Among those whose pulse rate rose between 11 and 40 per cent, both groups experienced comparable changes. In only 4 per cent of the patients given thiopentone did the pulse rate increase over 40 per cent, as compared to 29 per cent of the patients given propanidid.

Observations of ventilation revealed that six per cent of the patients receiving thiopentone hyperventilated, as compared to 88 per cent of the propanidid group. Patients induced with thiopentone did not hyperventilate beyond 10 seconds, as compared to 40 seconds for those induced with propanidid. The longest period of apnoea was approximately 60 seconds in each series. Forty per cent of the thiopentone group became apnoeic, while 75 per cent of the propanidid series were so affected.

Troublesome peroperative complications encountered are listed in Table IV.

TABLE IV

Peroperative Complications

\begin{tabular}{lcc}
\hline \hline & Thiopentone (\%) & Propanidid (\%) \\
\hline Laryngospasm & 3 & 5 \\
Bronchospasm & 0 & 0 \\
Coughing & 8 & 12 \\
Retching & 2 & 1 \\
Vomiting & 2 & 1 \\
Hiccough & 6 & 4 \\
\hline
\end{tabular}

Time intervals for the return of pain perception and a satisfactory level of consciousness for both groups are shown in Table V. The results indicate that patients induced with propanidid respond to painful stimuli and awaken more quickly than patients induced with thiopentone. 
508

CANADIAN ANAESTHETISTS' SOCIETY JOURNAL

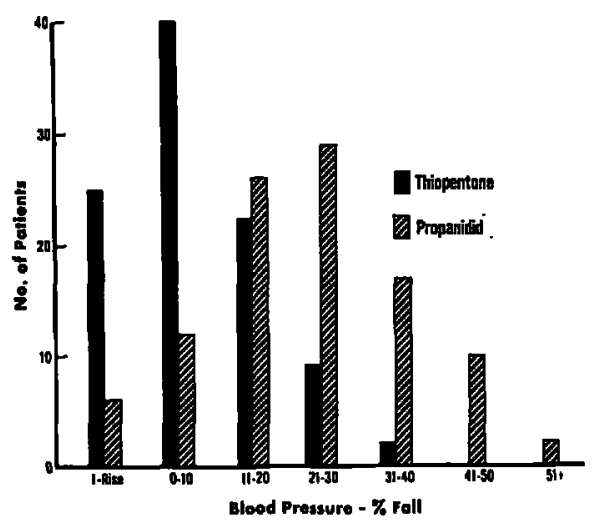

Figure 1. Blood pressure at one minute.

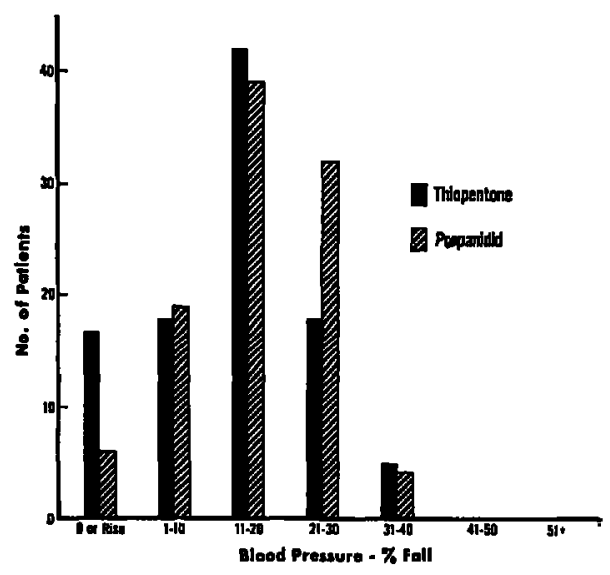

Figure 2. Blood pressure at three minutes.

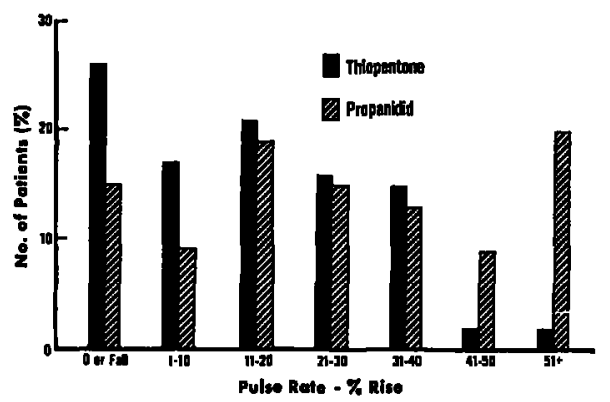

Figure 3. Pulse rate at one minute. 
TABLE V

ANAESTHESIA EMergence

\begin{tabular}{|c|c|c|c|c|c|c|}
\hline & \multicolumn{3}{|c|}{ Thiopentone } & \multicolumn{3}{|c|}{ Propanidid } \\
\hline & longest & shortest & mean & longest & shortest & mean \\
\hline $\begin{array}{l}\text { Return to pain: } \\
\text { halothane discontinued }\end{array}$ & 38.000 & 1.000 & 7.650 & 26.000 & 1.000 & 4.640 \\
\hline $\begin{array}{l}\text { Return to pain: } \\
\mathrm{N}_{2} \mathrm{O} \text { discontinued }\end{array}$ & 18.000 & 0.000 & 5.120 & 9.000 & 0.000 & 2.917 \\
\hline $\begin{array}{l}\text { Return to consciousness: } \\
\text { halothane discontinued }\end{array}$ & 42.000 & 3.000 & 12.200 & 35.000 & 2.000 & 7.830 \\
\hline $\begin{array}{l}\text { Return to consciousness: } \\
\mathrm{N}_{2} \mathrm{O} \text { discontinued }\end{array}$ & 25.000 & 1.000 & 9.670 & 19.000 & 0.000 & 5.889 \\
\hline
\end{tabular}

Postoperative questioning of the 200 patients revealed that 100 per cent of the patients induced with thiopentone had a pleasant recall of anaesthesia, as compared with 89 per cent of those induced with propanidid.

Table VI enumerates the commonly encountered postanaesthetic complications. Fourteen per cent of patients induced with propanidid were free of complications on awakening as compared to 4 per cent induced with thiopentone. Sixty-eight per cent of patients induced with thiopentone had some degree of postoperative drowsiness while 46 per cent of patients induced with propanidid were drowsy. Nineteen per cent of patients in the thiopentone series complained of headache, while 45 per cent of those in the propanidid series had headache. The incidence of nausea and vomiting is also shown.

TABLE VI

POSTOPERATIVE COMPLICATIONS

\begin{tabular}{|c|c|c|c|c|c|c|c|c|c|c|}
\hline & \multicolumn{2}{|c|}{ Drowsiness (\%) } & \multicolumn{2}{|c|}{ Headache (\%) } & \multicolumn{2}{|c|}{ Dizziness (\%) } & \multicolumn{2}{|c|}{ Nausea (\%) } & \multicolumn{2}{|c|}{ Vomiting (\% } \\
\hline & pent. & 1420 & pent. & 1420 & pent. & 1420 & pent. & 1420 & pent. & 1420 \\
\hline $\begin{array}{l}\text { Nil } \\
0-1 \mathrm{hr} . \\
1-4 \mathrm{hr} . \\
4-8 \mathrm{hr} . \\
8-12 \mathrm{hr} . \\
12-24 \mathrm{hr} . \\
\text { over } 24 \mathrm{hr} .\end{array}$ & $\begin{array}{r}32 \\
37 \\
23 \\
5 \\
1 \\
2 \\
0\end{array}$ & $\begin{array}{r}54 \\
25 \\
14 \\
4 \\
1 \\
2 \\
0\end{array}$ & $\begin{array}{r}81 \\
7 \\
6 \\
3 \\
2 \\
2 \\
0 \\
1\end{array}$ & $\begin{array}{r}55 \\
9 \\
15 \\
5 \\
8 \\
5 \\
3\end{array}$ & $\begin{array}{r}83 \\
5 \\
9 \\
2 \\
1 \\
1 \\
0 \\
0\end{array}$ & $\begin{array}{r}80 \\
8 \\
6 \\
1 \\
2 \\
1 \\
2\end{array}$ & $\begin{array}{r}88 \\
7 \\
1 \\
2 \\
1 \\
0 \\
1\end{array}$ & $\begin{array}{r}71 \\
15 \\
11 \\
1 \\
1 \\
0 \\
1\end{array}$ & $\begin{array}{r}97 \\
3 \\
0 \\
0 \\
0 \\
0 \\
0\end{array}$ & $\begin{array}{r}88 \\
7 \\
4 \\
1 \\
0 \\
0 \\
0\end{array}$ \\
\hline
\end{tabular}

Postoperative pain in the injection site was determined with each group. Ten per cent of the patients induced with thiopentone had discomfort, while 11 per cent in the propanidid series. had similar complaints. Two of the patients that received propanidid had mild phlebitis.

Table VII compares the two groups in their return to normal activity. The groups are similar.

The postoperative incidence of complications have high statistical significance ( $p$ value less than 0.01 ). 
TABLE VII

POSTOPERATIVE ACTIVITY

\begin{tabular}{lcc}
\hline \hline & $\begin{array}{c}\text { Thiopentone } \\
\text { (no. of patients) }\end{array}$ & $\begin{array}{c}\text { Propanidid } \\
\text { (no. of patients) }\end{array}$ \\
\hline Bed rest day of op. and first postop. & 2 & 4 \\
Bed rest after first postop. & 1 & 3 \\
Normal activity on return to ward & 69 & 61 \\
or home & 28 & 32 \\
Normal activity first postop. day & 28 \\
\hline
\end{tabular}

The changes in blood pressure, ventilation, apnoeic periods, awakening times, and postoperative complications have been statistically analysed and have a $p$ value of 0.01 .

\section{Discussion}

The experience gained in the use of propanidid revealed that $5 \mathrm{mg} . / \mathrm{kg}$. was in most instances an adequate induction dose. This is in agreement with an earlier study. ${ }^{1}$ The 23 per cent incidence of unsatisfactory dosage in the propanidid series probably indicates that some patients premedicated with atropine alone may require a higher dose per kilogramme of body weight.

A higher delivered concentration of halothane was required in the first three minutes of anaesthesia in patients induced with propanidid when compared to those induced with thiopentone. The initial high requirement of halothane in the propanidid group as compared to the thiopentone series is presumably due to the rapid rate of metabolism of propanidid. ${ }^{2}$ If a sufficient blood concentration of halothane is not obtained by three minutes, the patient will react to various stimuli.

In this investigation, one minute after injection an average fall of 22.2 per cent in mean blood pressure was found with propanidid and a 6.9 per cent fall with thiopentone. Wynands and Burfoot ${ }^{1}$ have shown that 60 per cent of their patients had a fall in mean blood pressure of $10-30$ per cent. Our present observations agree with these and those of Howells and Odell. ${ }^{2}$ These results are not in complete agreement with the findings of Dundee and Clarke, who found the cardiovascular effects of propanidid similar to those of thiopentone. ${ }^{4}$

Three minutes after injection the drugs were more comparable, the average decline in blood pressure being 16.2 per cent and 12.1 per cent with propanidid and thiopentone respectively. The comparable depression in mean blood pressure with the two agents at this time is presumably due to the effect of halothane. The tachycardia encountered during the hypotensive episode may be compensatory in nature or due to histamine release, as speculated by Wynands and Burfoot. ${ }^{1}$ The greater incidence and severity of hypotension and tachycardia when propanidid is used as an induction agent may contraindicate its use in the presence of cardiovascular insufficiency.

Investigators generally agree that induction with propanidid causes hyperventilation., 1,2,4 The hyperventilation caused no difficulties and allowed a greater uptake of halothane during the initial stages of anaesthesia. The greater inci- 
dence of apnoea with propanidid was more troublesome, necessitating ventilatory assistance in a greater number of patients.

The peroperative complications enumerated in Table IV are essentially equal with each agent. With the exception of one case, where the patient vomited during a period of light anaesthesia prior to attaining satisfactory halothane anaesthesia, the peroperative complications were not of a troublesome nature. The patient who vomited did not aspirate and made an uneventful recovery. He subsequently returned for the same procedure and was satisfactorily managed with a higher initial dose of propanidid.

None of the patients receiving thiopentone had reactions at the site of injection. Two per cent of the patients given propanidid had mild phlebitis. These results compare with previous reports. ${ }^{1,2,5}$

The incidence and severity of excitatory phenomena were peculiarly absent in this series as compared to others reported.1,2,8, This may be explained by the absence of premedicant drugs other than atropine as postulated by Clarke and Dundee. ${ }^{\top}$

A more rapid return to consciousness after propanidid in comparison to thiopentone has also been found by others. ${ }^{4}$ Twenty-two per cent more patients in the thiopentone series than in the propanidid series were inconvenienced because of drowsiness. On the other hand there was a greater incidence of headache, nausea, and vomiting after induction with propanidid. The 11 per cent of patients who had unpleasant memory of their anaesthetic in the propanidid series may have been influenced by this.

Despite the definite difference in postoperative complications in the two groups and the fact that more patients induced with propanidid were initially free of complaints, the marked similarity between the two groups in their time of return to normal activity may have been due to supplemental anaesthesia with $\mathrm{N}_{2} \mathrm{O}$ and Halothane.

\section{SUMMARY}

Experience with 200 cases, using 2.5 per cent thiopentone as an induction agent in 100 cases, and 5 per cent propanidid (FBA 1420) in the remainder, have been presented. Patients were compared during the induction, peroperative, emergence, and postoperative periods. A greater degree of hypotension, tachycardia, hyperpnoea, and apnoea were seen during induction with propanidid. Postoperatively, patients induced with thiopentone were drowsier, but had a smaller incidence of headache, nausea, and vomiting than those induced with propanidid. Patients in, both groups returned to activity in comparable time periods.

\section{RÉSUMÉ}

Les avancés du présent rapport sont la suite de l'expérience avec 200 cas, employant 2.5 pour cent thiopentone comme agent d'induction dans 100 cas et 5 pour cent propanidid (FBA 1420) dans les autres. Les patients ont été comparés pendant l'induction, période opératoire, au reveil et pendant la période postopératoire. Il s'est produit une plus grande proportion d'hypotension, de tachycardie et d'hyperpnée suivie d'apnée durant l'induction au propanidid. Dans 
la période postopératoire, les patients induits au thiopentone mettaient plus de temps au retour à la conscience. Cependant, avec thiopentone, on a noté une incidence moindre en ce qui concerne les céphalées, nausées et vomissements, en comparaison aux patients induis au propanidid. Les patients des deux groupes ont pris à peu près le même temps pour le retour aux activitiés normales.

\section{ACKNOWLEDGMENTS}

We wish to thank Dr. Werner Kober, of F.B.A. Pharmaceuticals Ltd., for his assistance in carrying out the project. We are also indebted to Dr. M. A. Stephens for his analysis of the data, and to Mrs. Patricia Sexsmith for her assistance during the study.

\section{REFERENCES}

1. Wynands, J. E. \& Burfoor, M. F. A Clinical Study of Propanidid (FBA 1420). Canad. Anaesth. Soc. J. 12: 587 (1965).

2. Howerls, T. H.; Odenx, J. R.; Hawkons, T. J.; \& SteANe, P. A. An Introduction to FBA 1420. Brit. J. Anaesth. 36: 295 (1964).

3. GoldMAN, V. \& KENNEDY, P. A Non-Barbiturate Intravenous Anaesthetic. Anesthesiology. 19: 424 (1964).

4. Dundee, J. W. \& Clarke, R. S. J. A Comparative Study of a New Eugenol Derivative, FBA 1420, with G29505 and Standard Barbiturates. Brit. J. Anaesth. 36: 100 (1964).

5. Swerdoow, M. A Trial of Propanidid (1420): A New Ultra-Short Acting Anaesthetic. Brit. J. Anaesth. 37: 785 (1965).

6. HarnicK, E. A Study of the Biphasic Ventilatory Effects of Propanidid. Brit. J. Anaesth. 36: 365 (1964).

7. Clanke, R. S. J. \& Dundee, J. W. Clinical Studies of Induction Agents: XII. The Influence of Some Premedicants on the Course and Sequelae of Propanidid Anaesthesia. Brit. J. Anaesth. 37: 51 (1965). 